\title{
Isolation and Characterization of Chemical Compounds From n-Hexane Extract of Zodia (Evodia suaveolens Scheff.) Leaves
}

\author{
Mutakin*, Wina Yunita, Titi W. Nikodemus \\ Departemen Analisis Farmasi dan Kimia Medisinal, Fakultas Farmasi, Universitas Padjadjaran, Jawa Barat, Indonesia
}

Submitted 25 February 2021; Revised 03 March 2021; Accepted 4 March 2021 ; Published 21 June 2021

*Corresponding author: mutakin@unpad.ac.id

\begin{abstract}
Zodia (Evodia suaveolens Scheff.) (Rutaceae) is one of Indonesia's native plants, which comes from Papua which is widely used as traditional medicine. Empirically, zodia leaves are used as anti-mosquitoes, dysentery drugs, boiled bark is useful as a reliever for malaria fever, leaf decoction is used as a tonic, and increases stamina. Until now, no investigation has been carried out for the main compounds of the zodia leaf n-hexane extract which have proven activity. Therefore, it was done the isolation and characterization of the main compound in the zodia leaf n-hexane extract (Evodia suaveolens $\mathrm{Sch}$.ff.). Zodia leaves were extracted with n-hexane using the Soxhlet apparatus. The n-hexane extract was fractionated using column chromatography with a gradient of $n$-hexane-chloroform mixture. Isolates were isolated in the form of white needle crystals which were purified by washing with n-hexane. Isolates was characterized by analyzing various UV, IR 1D and 2D NMR spectrometry data which were confirmed by analyzing the mass spectrum. Based on the results of spectrometric analysis, it is known that the isolate is thought to be a triterpenoid compound, namely neohop-e13 (18) -ene-3 $\alpha$-ol.
\end{abstract}

Keywords: Evodia suaveolens, neohope-13(18)-ene-3a-ol, triterpenoid

\section{Isolasi dan Karakterisasi Senyawa Kimia Ekstrak n-Heksan Daun Zodia (Evodia suaveolens Scheff.)}

\begin{abstract}
Abstrak
Zodia (Evodia suaveolens Scheff.) (Rutaceae) merupakan salah satu tumbuhan asli Indonesia, yaitu berasal dari Papua yang banyak dimanfaatkan sebagai obat tradisional. Secara empirik daun zodia digunakan sebagai anti nyamuk, obat disentri, rebusan kulit batangnya bermanfaat sebagai pereda demam malaria, rebusan daun dipakai sebagai tonik, dan penambah stamina tubuh. Sampai saat ini belum dilakukan penelusuran senyawa utama dari ekstrak n-heksan daun zodia yang terbukti memiliki aktivitas. Oleh karena itu dilakukan isolasi dan karakterisasi senyawa utama dalam ekstrak n-heksan daun zodia (Evodia suaveolens Scheff.). Daun zodia diekstraksi dengan n-heksan menggunakan alat Soxhlet. Ekstrak n-heksan difraksinasi menggunakan kromatografi kolom dengan campuran n-heksan-kloroform secara gradien. Isolat telah diisolasi berbentuk kristal jarum berwarna putih yang dimurnikan melalui pencucian dengan $\mathrm{n}$-heksan. Isolat dikarakterisasi dengan menganalisis berbagai data spektrometri UV, IM, RMI 1D dan 2D yang dikonfirmasi dengan menganalisis spektrum massa. Berdasarkan hasil analisis spektrometri diketahui bahwa isolat merupakan senyawa triterpenoid yaitu neohop-13(18)-ene-3 $\alpha$-ol.
\end{abstract}

Kata Kunci: Evodia suaveolens, neohop-13(18)-en-3 $\alpha$-ol, triterpenoid 


\section{Pendahuluan}

Zodia (Evodia suaveolens Scheff.) (Rutaceae) merupakan salah satu tumbuhan asli Indonesia, yaitu berasal dari Papua yang banyak dimanfaatkan sebagai obat tradisional. Secara empirik daun zodia digunakan sebagai anti nyamuk, obat disentri, rebusan kulit batangnya bermanfaat sebagai pereda demam malaria, rebusan daun dipakai sebagai tonik, dan penambah stamina tubuh. Perkembangbiakannya sangat mudah yaitu dengan menggunakan biji atau stek batang . ${ }^{1-6}$

Penelitian mengenai zodia masih sangat terbatas, terutama dilihat dari kandungan kimia maupun aktivitas biologisnya. Dalam Dictionary of Natural Products maupun pustaka lainnya belum dapat ditemukan hasil penelitian tumbuhan ini. Penelitian sejauh ini hanya sebagai anti nyamuk dan kandungan minyak atsirinya yang diketahui adalah linalool (46\%) dan $\alpha$-pinen. ${ }^{7}$ Aktivitas farmakologis dari daun zodia diperkirakan dihasilkan dari minyak atsiri yang akan terdapat pelarut non polar ${ }^{7}$, oleh karena itu penelitian ini akan difokuskan pada senyawa kimia utama yang terdapat pada ekstrak n-heksan sebagai pelarut yang baik dalam melarutkan minyak atsiri.

Mengingat banyaknya khasiat serta penggunaan sebagai obat tradisional oleh masyarakat dan hal ini tentunya merupakan efek dari senyawa kimia yang terkandung di dalamnya, maka diperlukan penelitian yang dapat dipertanggungjawabkan secara ilmiah. Oleh karena itu dilakukan penelitian yang bertujuan mengetahui senyawa kimia utama (major compound) yang terkandung dalam ekstrak n-heksan daun zodia serta metode isolasi dan karakterisasi dari senyawa tersebut.

\section{Metode}

2.1. Alat

Alat Soxhlet, rotary evaporator (Buchi), lampu ultraviolet (Camag UV-Betrachter), kolom kromatografi, spektrofotometer ultraviolet (Specord 200 Analytic Jena), spektrofotometer infra merah (FT-IR 8400 Shimadzu), kromatografi cair kinerja tinggi (Shimadzu LC 10 VP), spektrometer massa (Shimadzu GC-17, QP-5000 series), spektrofotometer resonansi magnet inti (JOEL).

\subsection{Bahan}

Bahan penelitian yang digunakan adalah daun zodia, metanol (Merck), n-heksan (Merck), kloroform (Merck), toluen (Merck), aseton (Merck), eter (Merck), etil asetat (Merck), asetonitril (Merck), asam klorida (Merck), gelatin (Merck), pereaksi Mayer, pereaksi Liebermann-Burchard, pereaksi Dragendorff, pereaksi vanilin-asam sulfat, tetrametil silen, silika gel 60 F254 (Merck), silica gel pro column 60 mesh (Merck), semua bahan kecuali dinyatakan lain memiliki grade pro-analisis.

\subsection{Prosedur Rinci}

\subsubsection{Determinasi Tumbuhan dan Ekstraksi}

Tumbuhan zodia dideterminasi di Laboratorium Taksonomi Tumbuhan, Jurusan Biologi, Fakultas Matematika dan Ilmu Pengetahuan Alam, Universitas Padjadjaran. Serbuk simplisia daun zodia diekstraksi secara sinambung menggunakan alat ekstraksi Soxhlet dengan cairan penyari n-heksan. Simplisia yang telah ditimbang, dimasukkan ke dalam labu Soxhlet. Ekstraksi dilakukan sampai tetesan pelarut hampir tidak berwarna. Ekstrak yang diperoleh diuapkan pelarutnya menggunakan rotary evaporator (40 sampai $50^{\circ} \mathrm{C}$ ) dengan kecepatan putar 40 rpm sehingga diperoleh ekstrak kental, penguapan dilanjutkan di atas penangas air pada suhu $40^{\circ} \mathrm{C}$ sampai berat ekstrak konstan dan dihitung rendemennya.

\subsubsection{Penapisan Fitokimia dan Kromatografi Lapis Tipis Ekstrak \\ Penapisan fitokimia dilakukan terhadap} simplisia dan ekstrak. Metode yang digunakan adalah metode Farnsworth. ${ }^{8}$ Kromatografi lapis tipis ekstrak n-heksana dilakukan dengan menggunakan fase diam silika gel 60 F254, fase gerak : n-heksan:kloroform (2:8) dan dideteksi menggunakan sinar tampak, sinar UV $366 \mathrm{~nm}$, penampak bercak vanillinasam sulfat kemudian diikuti pemanasan pada 100 sampai $105^{\circ} \mathrm{C}$. 


\subsubsection{Isolasi dan Karakterisasi Isolat} Fraksinasi ekstrak dilakukan menggunakan kromatografi kolom dengan kondisi :

$\begin{array}{ll}\text { Tinggi kolom } & : 40 \mathrm{~cm} \\ \text { Diameter kolom } & : 4 \mathrm{~cm} \\ \text { Fase diam } & : \text { silika gel pro column } \\ & 60 \text { mesh }\end{array}$

Fase gerak : :n-heksana : kloroform Sistem elusi : gradien

Pengemasan kolom dilakukan dengan melarutkan 214,63 g silika gel dalam gelas piala dengan fase gerak. Kemudian dituangkan secara perlahan-lahan ke dalam kolom sampai batas tertentu dan tidak terputus-putus. Silika dibiarkan turun sambil mengetuk-ngetuk dinding kolom, sehingga diperoleh kolom yang mampat dan kelebihan pelarut dikeluarkan melalui keran. Sebanyak $16.92 \mathrm{~g}$ ekstrak n-heksana digerus dengan silika gel sampai menjadi serbuk homogen. Kemudian diletakkan di atas kolom sedemikian rupa sehingga terbentuk pita yang siap untuk dielusi. Bagian atas sampel ditutup kembali dengan silika gel. Sampel dibiarkan meresap dulu ke dalam kolom, baru proses kromatografi dimulai yaitu mengelusi dengan campuran pelarut n-heksana : kloroform dalam 11 perbandingan $(10: 0,9: 1,8: 2,7: 3$, $6: 4,5: 5,4: 6,3: 7,2: 8,1: 9,0: 10)$. Fraksi yang keluar ditampung dan dilakukan pemantauan terhadap fraksi menggunakan kromatografi lapis tipis.

Kromatografi lapis tipis fraksi dilakukan dengan menggunakan fase diam silika gel 60 F254, fase gerak : toluene:aseton (99:1) dan dideteksi menggunakan sianr tampak, sinar UV $366 \mathrm{~nm}$, penampak bercak vanillin-asam sulfat kemudian diikuti pemanasan pada 100 sampai $105^{\circ} \mathrm{C}$. Fraksi dengan rendemen yang besar kemudian dilarutkan kembali dalam n-heksana pro analysis, dan diperoleh dua bagian. Bagian yang larut didekantasi, sedangkan endapan yang diperoleh dilarutkan kembali atau dilakukan pencucian dengan n-heksana. Pencucian ini dilakukan berulang kali sampai didapat endapan yang benarbenar terbebas dari bagain yang larut dalam n-heksana. Masing-masing bagian dipantau kembali menggunakan kromatografi lapis tipis dengan pengembang toluen : aseton (98:2). Isolat yang diperoleh terlebih dahulu dilakukan uji golongan dengan pereaksi Liebermann-Burchard, kemudian dianalisis menggunakan spektrofotometri ultraviolet, spektrofotometri inframerah, spektrometri massa, dan spektrometri resonansi magnet inti ( ${ }^{1} \mathrm{H}-\mathrm{RMI},{ }^{13} \mathrm{C}-\mathrm{RMI}, \mathrm{COSY}$, HMQC, dan $\mathrm{HMBC})$.

\section{Hasil}

3.1. Determinasi Tumbuhan dan Ekstraksi Hasil determinasi menunjukkan tumbuhan yang digunakan dalam penelitian termasuk famili Rutaceae, genus Evodia, spesies Evodia suaveolens Scheff. var. ridleyi (Hochr.) Bakh.f. Sebanyak 533 g serbuk daun zodia diekstraksi dengan alat Soxhlet sehingga diperoleh ekstrak berwarna hijau tua dengan rendemen $3,17 \%$.

\subsection{Penapisan Fitokimia dan Kromatografi Lapis Tipis Ekstrak \\ Penapisan fitokimia dilakukan terhadap} simplisia dan ekstrak. Hasil penapisan fitokimia dapat dilihat pada Tabel 1. Hasil kromatografi lapis tipis ekstrak dengan pengembang n-heksan : kloroform (2:8) dapat dilihat pada Tabel 2 .

\subsection{Isolasi dan Karakterisasi Isolat}

Sebanyak 16 g ekstrak n-heksan difraksinasi menggunakan kromatografi kolom, dielusi secara gradien dengan n-heksan : kloroform dan diperoleh 75 fraksi. Fraksi yang diperoleh dianalisis kembali menggunakan kromatografi lapis tipis dengan pengembang toluen : aseton (99:1) dan diperoleh 11 fraksi gabungan dengan pola bercak yang sama. Fraksi I $(2,2017 \mathrm{~g})$ dan fraksi J (0,6856 g) diisolasi lebih lanjut karena memiliki rendemen yang relatif lebih besar dan pola bercak yang terlihat relatif lebih mudah terpisah, yaitu melalui pencucian dengan n-heksan pro analysis. Hasil pencucian dianalisis kembali menggunakan kromatografi lapis tipis. Endapan yang diperoleh dari fraksi-fraksi tersebut larut dalam kloroform dan keduanya memberikan hasil satu bercak 
Tabel 1. Hasil Penapisan Fitokimia Simplisia dan Ekstrak n-Heksan

\begin{tabular}{ccc}
\hline Golongan & Simplisia & Ekstrak n-Heksan \\
\hline Alkaloid & + & - \\
Flavonoid & + & - \\
Polifenol & + & - \\
Tanin & - & - \\
Monoterpenoid dan & + & + \\
Seskuiterpenoid & - & - \\
Steroid & + & - \\
Triterpenoid & - & - \\
Kuinon & - & \\
Saponin & &
\end{tabular}

Keterangan : (+) : Terdeteksi; (-) : Tidak terdeteksi

$(\mathrm{Rf}=0,3)$ dengan pengembang toluen : aseton (99:1) yang dapat dilihat pada Tabel 3. Setelah pelarutnya menguap isolat diperoleh kembali dalam bentuk kristal jarum berwarna putih.

Analisis kualitatif isolat dilakukan dengan metode spektrofotometri UV dengan hasil isolat memiliki panjang gelombang maksimum pada $205 \mathrm{~nm}$. Pengukuran isolat dengan spektrofotometri infra merah menunjukkan adanya serapan pada $3468 \mathrm{~cm}$ $1,2946 \mathrm{~cm}^{-1}, 2856 \mathrm{~cm}^{-1}, 1632 \mathrm{~cm}^{-1}, 1464 \mathrm{~cm}^{-1}$, $1378 \mathrm{~cm}^{-1}$ dan $1068 \mathrm{~cm}^{-1}$. Pengukuran dengan spektrometri masa menghasilkan adanya fragmen ion $(\mathrm{M}+1) 427$ dan $(\mathrm{M}+2) 428$ yang berasal dari isotop oksigen. Hasil pengukuran dengan spektrofotometri UV, IR dan MS dapat dilihat pada Gambar 1. Pengukuran ${ }^{13} \mathrm{C}-\mathrm{RMI}$,
${ }^{1} \mathrm{H}-\mathrm{RMI}, 2 \mathrm{D}-\mathrm{COSY}, 2 \mathrm{D}-\mathrm{HMQC}, 2 \mathrm{D}-\mathrm{HMBC}$ memberikan hasil yang dapat dilihat pada Tabel 4.

\section{Pembahasan}

4.1. Determinasi Tumbuhan dan Ekstraksi Hasil determinasi menunjukkan tumbuhan yang digunakan dalam penelitian termasuk famili Rutaceae, genus Evodia, spesies Evodia suaveolens Scheff. var. ridleyi (Hochr.) Bakh.f. Ekstraksi yang dilakukan pada serbuk daun zodiac memberikan nilai rendemen $3.17 \%$.

\subsection{Penapisan Fitokimia dan Kromatografi Lapis Tipis Ekstrak \\ Berdasarkan hasil penapisan fitokimia} diketahui terdeteksi adanya golongan alkaloid,

Tabel 2. Hasil Kromatografi Lapis Tipis Ekstrak n-Heksan Daun Zodia

\begin{tabular}{ccccc}
\hline \multirow{2}{*}{ Bercak } & Rf & & \multicolumn{3}{c}{ Warna } & \\
\cline { 3 - 5 } & & Sinar tampak & Sinar UV 366 nm & Vanilin-asam sulfat \\
\hline 1 & 0,9 & kuning & coklat & ungu \\
2 & 0,79 & - & merah & ungu \\
3 & 0,68 & hijau tua & hitam kehijauan & hijau \\
4 & 0,61 & - & - & ungu \\
5 & 0,56 & - & ungu & hijau muda \\
6 & 0,52 & hijau tua & merah tua & hijau tua \\
7 & 0.45 & hijau tua & merah tua & hijau tua \\
8 & 0,34 & kuning & merah & abu-abu \\
9 & 0,22 & - & merah & abu-abu \\
\hline
\end{tabular}


Tabel 3. Hasil Kromatografi Lapis Tipis Fraksi I dan Fraksi J

\begin{tabular}{|c|c|c|c|c|c|c|}
\hline \multirow[b]{2}{*}{ Fraksi } & \multirow{2}{*}{$\begin{array}{c}\text { Rf } \\
\text { Fraksi I }\end{array}$} & \multirow{2}{*}{$\begin{array}{c}\text { Rf } \\
\text { Fraksi J }\end{array}$} & \multicolumn{2}{|c|}{ Warna Fraksi I } & \multicolumn{2}{|c|}{ Warna Fraksi J } \\
\hline & & & UV 366 nm & $\begin{array}{c}\text { Vanilin- } \\
\text { Asam Sulfat }\end{array}$ & UV 366 nm & $\begin{array}{c}\text { Vanilin- } \\
\text { Asam Sulfat }\end{array}$ \\
\hline \multirow[t]{4}{*}{ Awal } & 0,87 & 0,87 & biru & hijau-ungu & biru & hijau-ungu \\
\hline & 0,8 & 0,8 & biru & - & biru & - \\
\hline & 0,6 & 0,6 & - & ungu & - & ungu \\
\hline & & 0,4 & & & - & biru \\
\hline \multirow[t]{3}{*}{$\begin{array}{l}\text { Bagian } \\
\text { n-Heksan }\end{array}$} & 0,87 & 0,87 & biru & hijau-ungu & biru & hijau-ungu \\
\hline & 0,8 & 0,8 & biru & - & biru & - \\
\hline & & 0,4 & & & - & biru \\
\hline $\begin{array}{l}\text { Bagian } \\
\text { Klorofom }\end{array}$ & 0,6 & & - & ungu & & \\
\hline
\end{tabular}

flavonoid, polifenol, monoterpenoid dan seskuiterpenoid serta triterpenoid. Hasil KLT yang dilakukan pada ekstrak memperlihatkan adanya 9 bercak yang memberikan warna berbeda pada sinar UV $366 \mathrm{~nm}$ sesuai pada Tabel 2 yang menunjukkan adanya senyawa golongan triterpenoid.

\subsection{Isolasi dan Karakterisasi Isolat} Isolat yang secara organoleptik

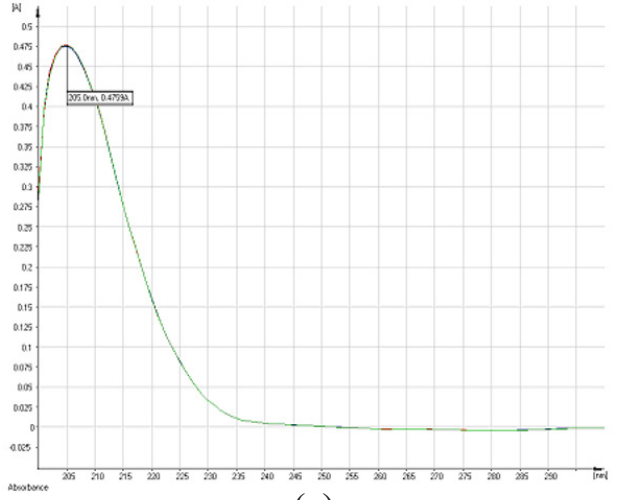

(a) berbentuk kristal jarum berwarna putih diduga merupakan suatu senyawa triterpenoid. Selain uji golongan dengan pereaksi LiebermannBurchard yang memberikan hasil positif (ungu $)^{8}$, isolat memiliki panjang gelombang maksimum pada $205 \mathrm{~nm}$ ( $\lambda$ maks triterpenoid: 190-210 nm). ${ }^{9}$ Isolat juga memiliki beberapa pita serapan pada spektrum IM yang umumnya dimiliki senyawa triterpenoid. Pita serapan pada $1378,63 \mathrm{~cm}^{-1}$ merupakan

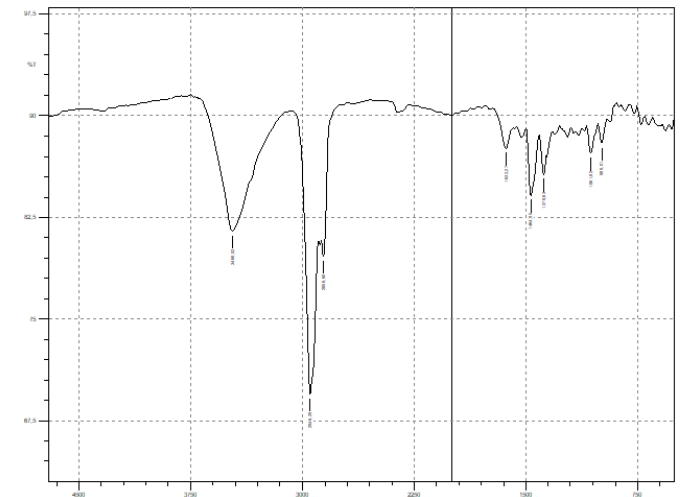

(b)

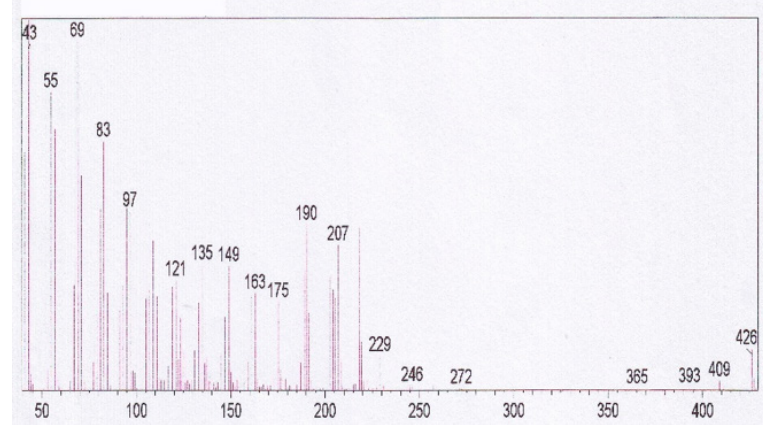

(c)

Gambar 1. Spektrum dari Spektrofotometri UV-Visibel (a), Spektrofotometri Infra Merah (b) dan Spektrometri Masa (c) dari Isolat 
Tabel 4. Hasil Pengukuran Spektrometri RMI 1D dan 2D

\begin{tabular}{|c|c|c|c|c|c|c|}
\hline \multirow{2}{*}{ No } & \multirow{2}{*}{${ }^{1} \mathrm{H}-\mathrm{RMI}$} & \multirow{2}{*}{$\begin{array}{c}{ }^{13} \mathrm{C} \text { RMI/ } \\
\text { HMQC }\end{array}$} & \multirow{2}{*}{ DEPT } & \multirow{2}{*}{ COSY } & \multicolumn{2}{|c|}{ НМВС } \\
\hline & & & & & ${ }^{2} \mathbf{J C H}$ & ${ }^{3} \mathbf{J C H}$ \\
\hline $1 \mathrm{a}$ & $1,28 \mathrm{ddd}$ & 33,7 & $\mathrm{CH} 2$ & $\mathrm{H} 2 \mathrm{~b}$ & $\mathrm{C} 2, \mathrm{C} 10$ & - \\
\hline $1 b$ & $1,49 \mathrm{ddd}$ & - & - & $\mathrm{H} 2 \mathrm{a}$ & - & - \\
\hline $2 \mathrm{a}$ & $1,54 \mathrm{~m}$ & 25,5 & $\mathrm{CH} 2$ & $\mathrm{H} 1 \mathrm{~b}, \mathrm{H} 3 \beta$ & $\mathrm{C} 1, \mathrm{C} 3$ & $\mathrm{C} 4, \mathrm{C} 10$ \\
\hline $2 b$ & $1,58 \mathrm{~m}$ & - & - & H1a & - & - \\
\hline $3 \beta$ & $3,39 \mathrm{t}$ & 76,3 & $\mathrm{CH}$ & $\mathrm{H} 2 \mathrm{a}, \mathrm{H} 2 \mathrm{~b}$ & - & $\mathrm{C} 1, \mathrm{C} 5, \mathrm{C} 23, \mathrm{C} 24$ \\
\hline 4 & - & 37,6 & $\mathrm{C}$ & - & - & - \\
\hline 5 & $1,21 \mathrm{dd}$ & 49,4 & $\mathrm{CH}$ & H6 & $\mathrm{C} 4, \mathrm{C} 6, \mathrm{C} 10$ & $\mathrm{C} 3, \mathrm{C} 9, \mathrm{C} 24, \mathrm{C} 7$ \\
\hline $6 \mathrm{a}$ & $1,43 \mathrm{~m}$ & 18,5 & $\mathrm{CH} 2$ & $\mathrm{H} 7 \mathrm{~b}, \mathrm{H} 5$ & C7 & $\mathrm{C} 4$ \\
\hline $6 b$ & $1,47 \mathrm{~m}$ & - & - & $\mathrm{H7a}$ & - & - \\
\hline $7 \mathrm{a}$ & $1,59 \mathrm{ddd}$ & 34,4 & $\mathrm{CH} 2$ & H6b & $\mathrm{C} 6, \mathrm{C} 8$ & $\mathrm{C} 5, \mathrm{C} 9$ \\
\hline $7 \mathrm{~b}$ & $1,62 \mathrm{ddd}$ & - & - & H6a & - & - \\
\hline 8 & - & 41,5 & $\mathrm{C}$ & - & - & - \\
\hline 9 & $1,45 \mathrm{dd}$ & 52,0 & $\mathrm{CH}$ & H11a, H11b & $\mathrm{C} 10, \mathrm{C} 8$ & $\begin{array}{l}\mathrm{C} 5, \\
\mathrm{C} 26\end{array}$ \\
\hline 10 & - & 42,7 & $\mathrm{C}$ & - & - & - \\
\hline $11 \mathrm{a}$ & $1,92 \mathrm{~m}$ & 26,7 & $\mathrm{CH} 2$ & $\mathrm{H} 12 \mathrm{~b}$ & $\mathrm{C} 9, \mathrm{C} 12$ & - \\
\hline $11 b$ & $2,19 \mathrm{~m}$ & - & - & - & - & - \\
\hline $12 \mathrm{a}$ & $1,84 \mathrm{~m}$ & 27,6 & $\mathrm{CH} 2$ & $\mathrm{H} 11 \mathrm{~b}$ & $\mathrm{C} 13$ & $\mathrm{C} 18$ \\
\hline $12 b$ & $1,88 \mathrm{~m}$ & - & - & - & - & - \\
\hline 13 & - & 131,6 & $\mathrm{C}$ & - & - & - \\
\hline 14 & - & 37,6 & $\mathrm{C}$ & - & - & - \\
\hline 15 & $1,24 \mathrm{~m}$ & 29,3 & $\mathrm{CH} 2$ & H16 & $\mathrm{C} 14, \mathrm{C} 16$ & - \\
\hline $16 \mathrm{a}$ & $1,27 \mathrm{ddd}$ & 38,0 & $\mathrm{CH} 2$ & $\mathrm{H} 15 \mathrm{~b}$ & $\mathrm{C} 17$ & $\mathrm{C} 18, \mathrm{C} 28$ \\
\hline $16 \mathrm{~b}$ & $1,78 \mathrm{ddd}$ & - & - & H15a & - & - \\
\hline 17 & - & 42,5 & $\mathrm{C}$ & - & - & - \\
\hline 18 & - & 141,2 & $\mathrm{C}$ & - & - & - \\
\hline $19 a$ & $2,29 \mathrm{~m}$ & 26,5 & $\mathrm{CH} 2$ & $\mathrm{H} 20 \mathrm{~b}$ & $\mathrm{C} 18$ & $\mathrm{C} 13, \mathrm{C} 21$ \\
\hline $19 b$ & $2,32 \mathrm{~m}$ & - & - & $\mathrm{H} 20 \mathrm{a}$ & - & - \\
\hline $20 \mathrm{a}$ & $1,35 \mathrm{~m}$ & 29,7 & $\mathrm{CH} 2$ & $\mathrm{H} 19 \mathrm{~b}$ & $\mathrm{C} 21, \mathrm{C} 19$ & - \\
\hline $20 \mathrm{~b}$ & $1,57 \mathrm{~m}$ & - & - & H19a & - & \\
\hline 21 & $1,04 \mathrm{q}$ & 59,2 & $\mathrm{CH}$ & $\mathrm{H} 22, \mathrm{H} 20 \mathrm{a}$ & $\mathrm{C} 17, \mathrm{C} 22$ & $\mathrm{C} 29, \mathrm{C} 30, \mathrm{C} 28$ \\
\hline 22 & 1,56 oktet & 29,9 & $\mathrm{CH}$ & $\begin{array}{l}\mathrm{H} 29, \mathrm{H} 30, \\
\mathrm{H} 21\end{array}$ & $\begin{array}{l}\mathrm{C} 21, \mathrm{C} 29, \\
\mathrm{C} 30\end{array}$ & - \\
\hline 23 & $0,94 \mathrm{~s}$ & 28,3 & $\mathrm{CH} 3$ & - & $\mathrm{C} 4$ & $\mathrm{C} 3, \mathrm{C} 5$ \\
\hline 24 & $0,82 \mathrm{~s}$ & 22,2 & $\mathrm{CH} 3$ & - & $\mathrm{C} 4$ & $\mathrm{C} 3, \mathrm{C} 5$ \\
\hline 25 & $0,83 \mathrm{~s}$ & 16,6 & $\mathrm{CH} 3$ & - & - & $\mathrm{C} 1, \mathrm{C} 9$ \\
\hline 26 & $0,85 \mathrm{~s}$ & 18,7 & $\mathrm{CH} 3$ & - & $\mathrm{C} 8$ & $\mathrm{C} 7$ \\
\hline 27 & $1,1 \mathrm{~s}$ & 26,8 & $\mathrm{CH} 3$ & - & $\mathrm{C} 14$ & $\mathrm{C} 13, \mathrm{C} 15, \mathrm{C} 21$ \\
\hline 28 & $0,79 \mathrm{~s}$ & 17,9 & $\mathrm{CH} 3$ & - & $\mathrm{C} 17$ & $\mathrm{C} 16, \mathrm{C} 21, \mathrm{C} 18$ \\
\hline 29 & $\begin{array}{c}0,88 \mathrm{~d}(J=6,7 \\
\mathrm{Hz})\end{array}$ & 23,2 & $\mathrm{CH} 3$ & $\mathrm{H} 22$ & $\mathrm{C} 22$ & $\mathrm{C} 21, \mathrm{C} 30$ \\
\hline 30 & $\begin{array}{c}0,92 \mathrm{~d}(J=6,7 \\
\mathrm{Hz})\end{array}$ & 22,9 & $\mathrm{CH} 3$ & $\mathrm{H} 22$ & $\mathrm{C} 22$ & $\mathrm{C} 21, \mathrm{C} 29$ \\
\hline
\end{tabular}


pita serapan khas untuk vibrasi regang gugus gem dimetil dari golongan triterpenoid ${ }^{9}$, pita serapan pada $1068,82 \mathrm{~cm}^{-1}$ merupakan pita serapan untuk $\mathrm{CH}_{2}$ sistem lingkar triterpenoid 9, dan daerah sidik jari $900-1400 \mathrm{~cm}^{-1}$ juga menunjukkan pola yang sama dengan senyawa triterpenoid. Selain itu isolat juga memiliki spektrum ${ }^{1} \mathrm{H}-\mathrm{RMI}$ yang khas untuk golongan triterpenoid yaitu mempunyai geseran proton yang rapat di bawah 2,4 ppm. Spektrum ${ }^{13} \mathrm{C}$-RMI dan DEPT menunjukkan isolat memiliki 30 atom karbon. Informasi ini juga menguatkan dugaan isolat, karena secara biosintesis triterpenoid dibentuk dari 6 unit isopren (C5). ${ }^{10}$

Berdasarkan spektrum ${ }^{13} \mathrm{C}-\mathrm{RMI}$ dan DEPT diketahui bahwa isolat memiliki 8 metil $\left(\mathrm{CH}_{3}\right)$ yang juga ditunjukkan oleh spektrum ${ }^{1} \mathrm{H}$-RMI, 10 metilen $\left(\mathrm{CH}_{2}\right), 5$ metin $(\mathrm{CH})$, dan 7 karbon kuartener (C). Sedangkan spektrum massa menunjukkan bahwa isolat memiliki berat molekul $\left(\mathrm{M}^{+}\right) 426$. Analisis lebih lanjut pada spektrum ${ }^{13} \mathrm{C}$-RMI menunjukkan adanya satu atom karbon yang teroksigenasi pada geseran 76,3 ppm yang juga ditunjukkan oleh spektrum ${ }^{1} \mathrm{H}-\mathrm{RMI}$ dengan adanya sinyal proton pada geseran 3,3 ppm berasal dari proton yang dekat dengan atom elektronegatif. ${ }^{10}$ Keberadaan atom oksigen ini juga ditunjukkan oleh spektrum massa dengan adanya fragmen ion $(\mathrm{M}+1)$ 427 dan $(\mathrm{M}+2) 428$ yang berasal dari isotop oksigen.

Berdasarkan informasi di atas diketahui isolat memiliki struktur molekul $\mathrm{C}_{30} \mathrm{H}_{50} \mathrm{O}$ dengan nilai DBE (double bond equivalent) sebesar 6. Dengan demikian isolat memiliki kerangka dasar 5 cincin dengan satu ikatan rangkap. Ikatan rangkap ditunjukkan dengan adanya 2 sinyal karbon $\mathrm{sp}^{2}$ pada geseran 131 dan 141 ppm yang berasal dari karbon kuartener (sinyal tidak muncul pada DEPT). Selain itu juga ditunjukkan oleh spektrum UV yaitu hanya memiliki satu $\lambda$ maks pada $205 \mathrm{~nm}$ yang dihasilkan oleh transisi elektron dari ikatan rangkap yang terisolasi (ikatan rangkap terkonjugasi menyerap pada panjang gelombang lebih tinggi). ${ }^{10}$ Spektrum IM juga menunjukkan keberadaan ikatan rangkap dengan adanya pita serapan pada bilangan gelombang $1632,27 \mathrm{~cm}^{-1}$ yang berasal dari vibrasi regang $\mathrm{C}=\mathrm{C} .{ }^{10}$

Spektrum IH-RMI menunjukkan 6 proton metil singlet pada $\delta \mathrm{H} 0,94 \mathrm{ppm}(\mathrm{H}-$ 23), 0,82 ppm (H-24), 0,83 ppm (H-25), 0,85 ppm (H-26), 1,1 ppm (H-27), 0,79 ppm (H28). Proton metil doublet ditunjukkan pada $\delta \mathrm{H} 0,88 \mathrm{ppm} ; \mathrm{J}=6,7 \mathrm{~Hz}(\mathrm{H}-29), 0,92 \mathrm{ppm} ; \mathrm{J}$ $=6,7 \mathrm{~Hz}(\mathrm{H}-30)$. Proton metin triplet pada $\delta \mathrm{H}$ 3,39 ppm berasal dari proton karbinolik yang diduga berada pada posisi C-3. Proton metin dengan multiplisitas oktet pada $\delta \mathrm{H} \quad 1,56$ ppm diduga berada pada posisi C-22. Proton metin dan metilen lain sangat kompleks dan beresonansi pada $\delta \mathrm{H} \mathrm{1,2-2,3} \mathrm{ppm.}$

Isolat diduga termasuk ke dalam triterpen hopanoid yang teroksigenasi. Hal ini disimpulkan dengan adanya rantai samping (R) isopropil pada posisi C21 yang ditentukan berdasarkan analisis data spektrum HMQC, COSY, dan HMBC. Atom oksigen pada isolat berasal dari gugus -OH yang ditunjukkan oleh spektrum IM dengan adanya pita serapan pada bilangan gelombang $3468,52 \mathrm{~cm}^{-1}$ yang berasal dari vibrasi regang $\mathrm{O}-\mathrm{H} .{ }^{11}$

Penentuan urutan dari atom karbon dilakukan dengan bantuan spektrum COSY dan HMBC, yang sebelumnya masingmasing karbon telah ditentukan proton pasangannya dengan bantuan HMQC. Selain itu juga dilakukan dengan membandingkan harga $\delta \mathrm{C}$ karbon isolat dengan atom-atom karbon dari senyawa hopanoid lainnya. Penentuan struktur isolat dimulai dari sinyal yang paling mudah yaitu dari sinyal proton triplet pada geseran $(\delta \mathrm{H}) 3,3$ ppm dengan geseran karbon $\delta \mathrm{C} 76,3$ ppm yang berasal dari proton karbinolik yang diduga terletak pada posisi 3. Tetapan penjodohan yang kecil dari proton karbinolik menunjukkan posisi proton karbinolik berada pada orientasi sedangkan gugus hidroksil terorientasi pada posisi $\alpha$ (posisi $\alpha \mathrm{J}$ di bawah $6 \mathrm{~Hz}$, posisi $\beta \mathrm{J}$ di atas $10 \mathrm{~Hz}){ }^{10,11}$ Selain itu, atom-atom karbon $\mathrm{C} 1$, $\mathrm{C} 2, \mathrm{C} 3$, dan C5 memiliki geseran sinyal yang lebih kecil (lebih shielded) dan karbon C24 memiliki geseran sinyal lebih besar (lebih deshielded) dibandingkan dengang gugus hidroksil yang terorientasi pada posisi $\beta .{ }^{11-13}$

Proton H3 memberikan korelasi 
HMBC dengan karbon metilen $\delta \mathrm{C} 33,7 \mathrm{ppm}$ ( $\delta \mathrm{H} 1,28 \& 1,49 \mathrm{ppm})$ dan korelasi COSY dengan proton pada geseran $\delta \mathrm{H}(1,54 \& 1,58$ ppm) ( $\delta \mathrm{C} 25,5 \mathrm{ppm})$, menunjukkan secara berurutan kedua metilen tersebut berada pada posisi 1 dan 2, yang dipertegas dengan adanya korelasi COSY $\mathrm{H} 2$ dengan $\mathrm{H} 3$ dan sebaliknya. Adanya dua geseran proton yang dimiliki proton metilen sebagai akibat dari orientasi aksial dan ekuatorial dari masingmasing proton metilen tersebut. Dua proton metil singlet pada geseran $\delta \mathrm{H} 0,94 \mathrm{ppm}$ ( $\delta \mathrm{C} 28,3 \mathrm{ppm})$ dan $\delta \mathrm{H} 0,82 \mathrm{ppm}(\delta \mathrm{C} 22,2$ ppm) keduanya memiliki korelasi HMBC dengan karbon kuartener pada $\delta \mathrm{C} 37,6 \mathrm{ppm}$ menunjukkan kedua metil tersebut terikat pada karbon kuarterner yang sama (gem dimetil). Spektrum HMBC juga menunjukkan adanya korelasi HMBC dari kedua proton metil tersebut dengan $\mathrm{C} 3$ dan sebaliknya sehingga diduga berada pada posisi 4 seperti yang umum terdapat pada senyawa triterpenoid. Masing-masing metil di atas secara berurutan berada pada posisi 23 dan 24. Proton metil singlet $\delta \mathrm{H} 0,85 \mathrm{ppm}(\delta \mathrm{C} 18,7 \mathrm{ppm})$ memiliki korelasi HMBC dengan karbon kuartener $\delta \mathrm{C} 41,5$ dan karbon metilen $\delta \mathrm{C} 34.4 \mathrm{ppm}$ ( $\delta \mathrm{H} 1,59 \& 1,62 \mathrm{ppm})$. Ketiganya secara berurutan menunjukkan posisi 26, 8, dan 7 . Adanya korelasi HMBC proton metilen $\mathrm{H} 7$ dengan C8 dan C6 dan korelasi COSY dengan proton H6 mempertegas kedudukan metilen ini pada posisi 7. Proton metil singlet $\delta \mathrm{H} 0,83$ ppm ( $\delta \mathrm{C} 16,6 \mathrm{ppm})$ memiliki korelasi HMBC dengan $\mathrm{C} 9$ dan $\mathrm{C} 1$ sehingga menunjukkan kedudukannya pada posisi 25. Korelasi HMBC yang ditunjukkan proton metil singlet $\delta \mathrm{H} 1,1 \mathrm{ppm}$ ( $\delta \mathrm{C} 26,8 \mathrm{ppm}$ ) terhadap karbon kuartener $\delta \mathrm{C} 37,6 \mathrm{ppm}$ dan $\delta \mathrm{C} 131,6$ dengan kontur HMBC yang lebih besar terhadap karbon kuartener $\delta \mathrm{C} 37,6$, memberikan gambaran keduanya secara berurutan berada pada posisi 14 dan 13. Sedangkan metilnya diduga pada posisi 27 , karena adanya korelasi HMBC terhadap C8.

Proton metilen $\delta \mathrm{H} \quad(1,92 \quad \& \quad 2,19$ ppm) ( $\delta \mathrm{C} 26,7 \mathrm{ppm}$ ) menunjukkan korelasi HMBC dengan $\mathrm{C} 10$ dan dengan karbon metilen $\delta \mathrm{C} 27,6 \mathrm{ppm}(\delta \mathrm{H} 1,84 \& 1,88 \mathrm{ppm})$ yang protonnya berkorelasi HMBC dengan
C13. Informasi ini memberikan gambaran keduanya berada pada posisi 11 ( $\delta \mathrm{C} 26,7$ ppm) dan 12 ( $\delta \mathrm{C} 27,6 \mathrm{ppm}$ ). Proton metilen H12 memberikan korelasi yang lebih lemah terhadap karbon kuartener 141 dibandingkan terhadap karbon kuartener pada posisi 13. Dengan demikian diduga karbon kuartener 141,2 berada 3 ikatan dari H12 yaitu pada posisi 18. Posisi ikatan rangkap ini diperkuat dengan tidak adanya sinyal dari proton oleofenik yang muncul di sekitar geseran 5 ppm maupun pita serapan dari C-H oleofenik yang menyerap dengan intensitas lemahsedang pada bilangan gelombang 3000-3100 cm-1 14. Pada spektrum HMBC proton metil singlet $\delta \mathrm{H} 0,79 \mathrm{ppm}(\delta \mathrm{C} 17,9 \mathrm{ppm})$ memberikan korelasi selain terhadap karbon C18 juga terhadap karbon kuartener $\delta \mathrm{C} 42,5$ ppm. Karbon kuartener ini diduga pada posisi 17 dan metilnya pada posisi 28. Proton metil ini juga memberikan korelasi HMBC dengan metilen $\delta \mathrm{H}(1,27 \& 1,78 \mathrm{ppm})(\delta \mathrm{C} 38.0 \mathrm{ppm})$ dan metin $\delta \mathrm{H} \mathrm{1,04} \mathrm{ppm} \mathrm{(} \delta \mathrm{C} 59,2$ ppm) dengan kontur yang sama besar dan diasumsikan keduanya berada pada jarak ikatan yang sama terhadap H28 yaitu secara berurutan pada posisi 16 dan 21. Posisi ini tidak mungkin berkebalikan karena sangat sulit dijelaskan secara biogenesis, meskipun diduga berasal dari senyawa yang benar-benar baru.

Isolat memiliki rantai samping isopropil yang terikat pada karbon C21. ${ }^{1} \mathrm{H}-\mathrm{RMI}$ menunjukkan adanya dua sinyal metil yang memiliki multiplisitas doublet dengan tetapan penjodohan yang sama sebesar $\mathrm{J}=6,7 \mathrm{~Hz}$. Ini menunjukkan kedua metil tersebut terikat pada karbon metin yang sama (gem dimetil). Kedudukan rantai samping ini, diperkuat dengan adanya korelasi HMBC dari kedua proton metil doublet $\delta \mathrm{H} 0,88 \mathrm{ppm}(\delta \mathrm{C} 23,2$ ppm; $\mathrm{J}=6,7 \mathrm{~Hz})$ dan $\delta \mathrm{H} 0,94 \mathrm{ppm}(\delta \mathrm{C} 22,9$ ppm $\mathrm{J}=6,7 \mathrm{~Hz}$ ) terhadap $\mathrm{C} 21$ dan sebaliknya. Proton-proton metil ini juga berkorelasi dengan karbon metin oktet $\delta \mathrm{H} 1,56 \mathrm{ppm}(\delta \mathrm{C}$ 29,9 ppm) yang diduga berada pada posisi 22 . Korelasi COSY dari H29, H30, H22, dan H21 menguatkan dugaan adanya rantai samping isopropil pada posisi 21. Karbon C21 juga mendapat korelasi HMBC jarak jauh dari H27 dengan jarak lebih dari 3 ikatan. Pada 


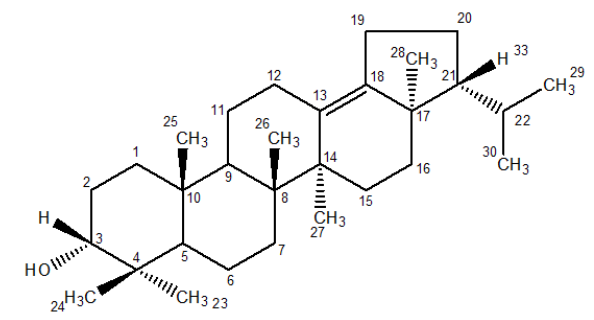

Gambar 2. Struktur kimia isolat (neohope-13(18)-ene-3 $\alpha$-ol)

umumnya korelasi HMBC memberikan gambaran adanya interaksi antara proton dengan karbon yang berjarak 2-3 ikatan. Walaupun demikian interaksi HMBC lebih dari tiga ikatan mungkin terjadi karena adanya konformasi 3D (konformasi ruang). Dengan demikian diduga proton $\mathrm{H} 27$ dengan karbon C21 secara stereokimia memiliki konformasi yang berdekatan. ${ }^{14,15}$

Proton metilen $\delta \mathrm{H}(2,29 \& 2,32 \mathrm{ppm})$ ( $\delta \mathrm{C} 26,5 \mathrm{ppm})$ memberikan korelasi HMBC dengan karbon $\mathrm{C} 18, \mathrm{C} 13$ (kontur yang lebih kecil dibandingkan kontur terhadap $\mathrm{C} 18$ ), serta C21. Hal ini menunjukkan kedudukannya pada posisi 19. Sedangkan proton metilen $\delta H$ (1,35 \& 1,57 ppm) ( $\delta \mathrm{C} \mathrm{29,7} \mathrm{ppm)} \mathrm{memiliki}$ korelasi HMBC dengan C19 dan C21, menunjukkan kedudukannya pada posisi 20 yang dikuatkan dengan korelasi COSY dari ketiganya.

Pemastian kedudukan dari masingmasing karbon dilakukan berdasarkan korelasi yang diberikan pada spektrum COSY. Hal ini dikarenakan kompleksnya bentuk kontur yang terjadi sebagai akibat interaksi yang kompleks dalam senyawa triterpenoid. Spektrum COSY menunjukkan adanya korelasi antara $\mathrm{H} 3$ dengan $\mathrm{H} 2, \mathrm{H} 2$ dengan H1, H21 dengan H20 dan H22, H22 dengan $\mathrm{H} 29$ dan $\mathrm{H} 30$ dengan $\mathrm{H} 1$, $\mathrm{H} 21$ dengan H20 dan H22, H22 dengan H29 dan H30.

Berdasarkan hasil interpretasi berbagai data spektrum dan hasil reaksi kimia, isolat merupakan senyawa neohope-13(18)-ene-3 $\alpha$ ol dengan struktur kimia yang dapat dilihat pada Gambar 2. Hal ini diperkuat dengan adanya kemiripan geseran metil pada isolat (neohope-13(18)-ene-3 $\alpha$-ol) dengan geseran metil pada senyawa neohop-13(18)-ene.

\section{Kesimpulan}

Berdasarkan hasil penelitian diketahui bahwa senyawa triterpenoid merupakan senyawa utama (major compound) dalam ekstrak n-heksan. Hasil karakterisasi isolat dengan menginterpretasi data spektrum UV, IM, ${ }^{1} \mathrm{H}-\mathrm{RMI},{ }^{13} \mathrm{C}-\mathrm{RMI}, \mathrm{COSY}$, HMQC, dan HMBC serta dipastikan dengan menganalisis spektrum massa menunjukkan bahwa isolat termasuk dalam golongan triterpen hopanoid dan diduga terkarakterisasi sebagai Neohope13(18)-ene-3 $\alpha$-ol. Hasil perbandingan geseran proton, geseran karbon dan pola fragmentasi dengan senyawa hopanoid lain, isolat menunjukkan kemiripan paling besar dengan senyawa Neohope-13(18)-ene.

\section{Daftar Pustaka}

1. R1. Guastaldi R, Reis A, Figueras A, Secoli S. Prevalence of potential drug-drug interactions in bone marrow transplant patients. Int $\mathrm{J}$ Clin Pharm. 2011;33(6):1002-9.

2. 2. L. Susanti, H. Boesri. Toksisitas Biolarvasida Ekstrak Tembakau dibandingkan dengan Ekstrak Zodia terhadap Jentik Vektor Demam Berdarah Dengeu (Aedes Aegypti). Bul. Pen. Kes. 2012;40:75-84,

3. 3. Evi Mintowati Kuntorini E.M, Nofaliana D., and Pujawati E.D, Anatomical Structure and Terpenoid Content of Zodia (Evodia suaveolens Scheff) Leaves, BIO Web of Conferences, 2020; 20:03001

4. 4. Mirawati P, Simareme E.V, Pratiwi R.D. Uji Efektivitas Repellent Sediaan Lotion Kombinasi Minyak Atsiri Daun Zodia (Evodia suaveolens Scheff) dan minyak atsiri batang serai (Cymbopogon citratrus) terhadap Nyamuk Aedes aegypti L, Pharmacy: Jurnal Farmasi Indonesia,2018; 15(1):1-15

5. 5. Lestari, F.D dan Simareme E,S, Uji 
Potensi Minyak Atsiri daun Zodia (Evodia suaveolens Scheff) sebagai insektisida nyamuk Aedes Aegypti dengan metode elektrik, Pharmacy, 2017;14(1): 1-10

6. 6. Simareme E.S., Manurung, L., Gunawan E, dan Maryuni, A.E, Zodia (Evodia suaveolens Scheff) in liquid soap as repellent against Aedes aegypti K. Advances Scienes Letters, 2018; 24:9194

7. 7. Kardinan, A. 2004. Zodia (Evodia suaveolens) : Tanaman Pengusir Nyamuk. www.litbang.deptan.go.id, diakses 11 Februari 2020

8. 8. Farnsworth, N.R. Biological and Phytochemical Screening of Plant. J. Pharm. Sci. 1966; 55(3): 243-269

9. 9. Branco,Alexandro, A. Pinto, Ramundo B. F. Chemical Constituens from Vellozia graminifolia (Velloziaceae). An. Acad. Braz. Cienc. 2004;76(3): 505-518

10. 10. Akihisa, Toshihiro \& L. John Goad. Analysis of Sterols. Blackie Academic \& Professional. Tokyo. Japan. 1997; 2:2339

11. 11. Sanora, G., Mastura, E. Y., Handoyo, M. O. M., \& Purnama, E. R. Identification of Anticancer Active Compound from GC-MS Test Results of Zodia Leaves (Evodia suaveolens) Ethanol Extract. Jurnal Biota, 2019;5(2):89-95.

12. 12. Gunawidjaja N.P., An Overview of Nuclear Magnetic Resonance, Integral, 2013; 11(1):27-39

13. 13. Liang Q., Wang Q.,Wang Y., Wang Y.N., Hao.J., Jiang M. Quantitative 1H-NMR Spectroscopy for Profiling Primary Metabolites in Mulberry Leaves, Molecules, 2018; 23(3):554

14. 14. Hadi M., , Setiyadi D., Mawarni A., Martini M. , Sutiningsih D.,Suwondo A., Potential of Zodia Leaf Extracts of Hexane Solvent in Reducing Aedes aegypti Density: Semi-Field Trial Application in Endemic Areas of Dengue Hemorrhagic Fever (DHF), Annals of Tropical Medicine \& Public Health, 2021;24(1):1-7

15. 15. Ngibad K., Lestari L.P.,. ISSN : 20854714161 Uji Fitokimia Dan Aktivitas Antioksidan Ekstrak Metanol Daun Zodia (Evodia suaveolens), As-Syifaa Jurnal Farmasi, 2019; 11 (2):161-168 